\title{
Effects of Lysosomal Protease Inhibitors on the Degradation of Acetylated Low Density Lipoprotein in Cultured Rat Peritoneal Macrophages
}

\author{
Takeo Kuroda, Mototaka Yoshinari, Ken Okamura, Kaeko Okazawa, \\ Hiroshi Ikenoue, Kaori Sato, and Masatoshi Fujishima
}

Second Department of Internal Medicine, Faculty of Medicine, Kyushu University, Fukuoka, Japan.

\begin{abstract}
The effect of protease inhibitors, leupeptin and pepstatin A, on the metabolism of acetylated low density lipoprotein (acetyl-LDL) was investigated in cultured rat peritoneal macrophages and compared with that of chloroquine. While both leupeptin and pepstatin inhibited the proteolytic degradation of ${ }^{125} \mathrm{I}$-acetyl-LDL, a combination of both showed an additive effect. Similar to chloroquine, both protease inhibitors diminished $\left[{ }^{3} \mathrm{H}\right]$ oleate incorporation into cellular cholesteryl $\left[{ }^{3} \mathrm{H}\right]$ oleate and increased cholesterol content of macrophages. These results suggest that both thiol protease and cathepsin D participate in the physiological degradation of apolipoprotein in macrophages. The inhibition of apolipoprotein degradation seemed to have an effect on cholesterol metabolism in macrophages cultured with acetylLDL. J Atheroscler Thromb, $1994 ; 1$ : 41-44.
\end{abstract}

Key words : Leupeptin, Pepstatin A, Chloroquine

Acetyl-LDL accumulates in macrophages via scavenger receptors, where it is degraded by lysosomes $(1,2)$. Apolipoproteins are digested by lysosomal proteases, while cholesteryl esters in the lipoprotein are hydrolyzed by lysosomal acid lipase $(1,2)$. As for the proteases, the results of in vitro studies suggest that thiol proteases and cathepsins participate in the degradation of apolipoproteins, using methods such as sonicated macrophages (3), subcellular fractions of macrophages (4), or a direct incubation of lipoprotein with cathepsins (5). However, their roles in cell culture systems have been obscure. Therefore, we examined the effect of lysosomal protease inhibitors on the metabolism of acetyl-LDL in cultured rat peritoneal macrophages.

Address for correspondence: Takeo Kuroda, M.D., Second Department of Internal Medicine, Faculty of Medicine, Kyushu University 60, Maidashi 3-1-1, Higashi-ku, Fukuoka city 812, Japan.

Received September 16, 1993.

Accepted for publication October 21, 1993.

Abbreviations: acetyl-LDL, acetylated low density lipoprotein; HBSS, Hank's balanced salt solution; TLC, thin layer chromatography; TCA, trichloroacetic acid; This work was presented at the 22th Annual Meeting of the Japan Atherosclerotic Society on December 14, 1990, Miyazaki.

\section{Materials and Methods}

\section{Materials}

Leupeptin and pepstatin A were purchased from Peptide Institute, Inc. (Osaka, Japan). Chloroquine diphosphate, HBSS, and bovine serum albumin (BSA) were purchased from Sigma Chemical Co. (St. Louis, MO). Eagle's minimum essential medium (EMEM) was purchased from Nissui Seiyaku Co., Ltd. (Tokyo, Japan). Fatal calf serum (FCS) was purchased from Gibco (Grand Island, NY). Thioglycollate broth was purchased from Gifco Laboratories (Detroit Michigan, USA), 24-well (16 $\mathrm{mm}$ in diameter) culture plates from Costar (Cambridge, MA), and plates for TLC from Whatman International Ltd. (Meidstone, England) were purchased. Male SpragueDawley (SD) rats were purchased from Kyudo Co., Ltd. (Kumamoto, Japan). $\mathrm{Na}\left[{ }^{125 \mathrm{I}}\right],\left[9,10(\mathrm{~N})-{ }^{3} \mathrm{H}\right]$ oleate $(2.2$ $\mathrm{GBq} / \mathrm{mmol}$ ), and cholesteryl $\left[1-{ }^{14} \mathrm{C}\right]$ oleate $(370 \mathrm{GBq} /$ $\mathrm{mmol})$ were purchased from Amersham Japan Co., Ltd. (Tokyo, Japan).

\section{Lipoproteins}

LDL $(d=1.019-1.063 \mathrm{~kg} / \mathrm{L})$ was isolated from human serum obtained from healthy fasting subjects by the differential ultracentrifugation method (6), then dialyzed 
against $0.15 \mathrm{M} \mathrm{NaCl}$ with $5 \mathrm{mM}$ MOPS buffer (pH 7.4). LDL was acetylated by repeated addition of acetic anhydride in half-saturated sodium acetate solution (7). Lipoproteins were labelled with ${ }^{125}$ by the $\mathrm{ICl}$ method $(8,9)$. Specific activity of radiolabeled lipoprotein was $70-148$ $\mathrm{cpm} / \mathrm{ng}$. Less than $2 \%$ of the total radioactivity was TCA $(10 \%)$ soluble or chloroform-methanol $(2: 1, \mathrm{v} / \mathrm{v})$ extractable. After isolation, the lipoprotein was kept at $4{ }^{\circ} \mathrm{C}$ and used within a week.

\section{Macrophage monolayer culture}

Peritoneal cells were harvested in HBSS from male SD rats weighing $250-350 \mathrm{~g}, 3$ days after an intraperitoneal injection of $2.5 \%$ thioglycollate $(60 \mathrm{ml} / \mathrm{kg}$ body weight). The cells were collected and washed with HBSS twice, then suspended in EMEM to make a solution of 1-2 x106 cells $/ \mathrm{ml}$, and dispensed on culture plates $(1 \mathrm{ml} /$ well). They were preincubated under humidified $5 \% \mathrm{CO}_{2}$ at $37^{\circ} \mathrm{C}$ for 1 hour, then washed three times with HBSS to remove nonadherent cells. The resulting adherent macrophages were incubated in EMEM supplemented with 10\% FCS and $100 \mu \mathrm{g} / \mathrm{ml}$ of acetyl-LDL, in the presence or absence of inhibitors. The $\left[{ }^{3} \mathrm{H}\right]$ oleate-BSA complex was prepared according to Goldstein et al. (10) for determination of $\left[{ }^{3} \mathrm{H}\right]$ oleate incorporation.

\section{Assays}

After incubation, the cells were washed with HBSS (2 $\mathrm{ml} /$ well) containing $0.2 \% \mathrm{BSA}$ at $4^{\circ} \mathrm{C}$ three times, then dissolved in $0.4 \mathrm{ml} /$ well of $0.1 \mathrm{~N} \mathrm{NaOH}$ (11). The whole sample was used to determine the intracellular ${ }^{125}$-acetylLDL, then an aliquot was used to measure cellular protein content. Proteolytic degradation of 125 -lipoprotein was determined by measuring the $10 \%$ TCA soluble ${ }^{125}$-labeled material released into the culture medium. TCA soluble ${ }^{125}$ activity derived from spontaneous degradation of lipoprotein during incubation was measured with a cell-free well after a parallel incubation, and subtracted as a blank. Free iodine was removed according to the method of Goldstein et al. (12). The amount of $\left[{ }^{3} \mathrm{H}\right]$ oleate incorporated into cellular cholesteryl $\left[{ }^{3} \mathrm{H}\right]$ oleate was determined by $\mathrm{TLC}$, using cholesteryl $\left[{ }^{14} \mathrm{C}\right]$ oleate as an internal standard (10). TLC was developed with hexane-ethyl ether$1 \%$ acetic acid $(79: 20: 1)$ solution. The recovery of cholesteryl $\left[{ }^{14} \mathrm{C}\right]$ oleate after TLC was $71 \pm 7 \% \quad(n=30)$. Cellular contents of total and free cholesterol were analyzed by the fluorescent method (13). Concentration of the lipoprotein was expressed as protein content, measured by the Bio-Rad protein assay kit (Bio-Rad Laboratories, Richmond, CA).

\section{Statistics}

Statistical analysis was performed by analysis of variance. Each experiment was performed in triplicate and the results were expressed as mean $\pm S D$.

\section{Results}

Effect of inhibitors on the degradation of ${ }^{125}$-acetyl-LDL As shown in Table 1, both leupeptin and pepstatin caused a significant decrease in the degradation of 125 acetyl-LDL accompanied by an increase in ${ }^{125}$ activity within the cells. It is known that chloroquine has a similar effect. Cellular protein contents were significantly higher when incubated with leupeptin and pepstatin together, but not with chloroquine. These findings indicate that these inhibitors act by inhibiting apolipoprotein degradation. A combination of leupeptin and pepstatin

Table 1. Effect of protease inhibitors and chloroquine on ${ }^{125}$-acetyl-LDL metablolhsm in cultured macrophage.

\begin{tabular}{|c|c|c|c|c|c|}
\hline & Control & Leupeptin & Pepstatin & $\begin{array}{l}\text { Leupeptin } \\
\text { +Pepstatin }\end{array}$ & Chloroquine \\
\hline Degraded & $1.24 \pm 0.11$ & $0.54 \pm 0.07^{* * *}$ & $0.68 \pm 0.06^{* * *}$ & $0.43 \pm 0.07^{* * *}$ & $0.27 \pm 0.18^{* * *}$ \\
\hline Accumulated & $0.27 \pm 0.01$ & $0.34 \pm 0.01 * *$ & $0.30 \pm 0.01$ & $0.51 \pm 0.01 * * *$ & $0.60 \pm 0.04^{* * *}$ \\
\hline Protein & $190 \pm 2$ & $208 \pm 12^{*}$ & $219 \pm 4^{* *}$ & $241 \pm 7^{* * *}$ & $200 \pm 4$ \\
\hline
\end{tabular}

Macrophages were incubated with $100 \mu \mathrm{g} / \mathrm{ml}$ of ${ }^{125} /$-acetyl-LDL for 5 hours. Concentration of each inhibitor in the media was as follows: Leupeptin $100 \mu \mathrm{g} / \mathrm{ml}$, Pepstatin $100 \mu \mathrm{g} / \mathrm{ml}$, Chloroquine $75 \mu \mathrm{M}$. Degraded: Degraded ${ }^{125}$-acetyl-LDL ( $\mu \mathrm{g} /$ well) estimated as TCA soluble non-iodide ${ }^{125} \mathrm{l}$ activities in the media. Accumulated: Accumulated ${ }^{125} \mathrm{I}$-acetyl-LDL $\left(\mu \mathrm{g} /\right.$ well) to the macrophages estimated as ${ }^{125} \mathrm{I}$ activities ascribed to the cells at the end of the incubation. Protein: Protein content of the macrophages (mg/well) after incubation. Values shown are the mean \pm SD $(n=3) .\left({ }^{*} p<0.05,{ }^{* *} p<0.005,{ }^{* * *} p<0.001\right.$ vs control)

Table 2. Effect of protease inhibitors and chloroquine on $\left[{ }^{3} \mathrm{H}\right]$ oleate incorporation into cellular cholestery $\left[{ }^{3} \mathrm{H}\right]$ oleate.

\begin{tabular}{|c|c|c|c|c|}
\hline Control & Leupeptin & Pepstatin & $\begin{array}{l}\text { Leupeptin } \\
+ \text { Pepstatin }\end{array}$ & Chloroquine \\
\hline $0.89 \pm 0.01$ & $0.68 \pm 0.10^{*}$ & $0.70 \pm 0.14^{*}$ & $0.65 \pm 0.03^{*}$ & $0.25 \pm 0.04^{* *}$ \\
\hline
\end{tabular}

Macrophages were incubated with $100 \mu \mathrm{g} / \mathrm{ml}$ of acetvl-LDL together with $0.1 \mathrm{mM}$ of $\left[{ }^{3} \mathrm{H}\right]$ oleate for 5 hours. Results are given as the dose of $\left[{ }^{3} \mathrm{H}\right]$ oleate incorporated into cellular cholestery $\left[{ }^{3} \mathrm{H}\right]$ oleate $(\mathrm{nmol} /$ well), and expressed as mean \pm $\mathrm{SD}$ of triplicate wells. The control value, $0.89 \pm 0.01 \mathrm{nmol} /$ well, corresponds with $3.2 \mathrm{nmol} / \mathrm{mg}$ cell protein.

$\left({ }^{*} \mathrm{p}<0.05,{ }^{* *} \mathrm{p}<0.001\right.$ vs control) 


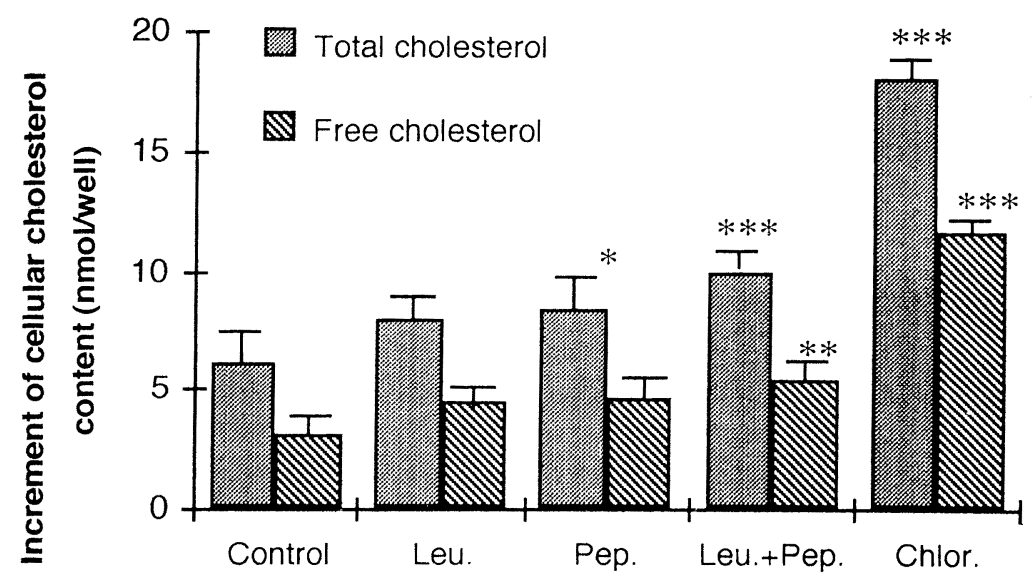

Fig. 1. Effect of protease inhibitors and chloroquine on cholesterol content of macrophages. Macrophages were incubated with $100 \mu \mathrm{g} / \mathrm{ml}$ of acetyl-LDL for 5 hours in the presence or absence of the inhibitors ; Leupeptin (Leu.) $100 \mu \mathrm{g} / \mathrm{ml}$, Pepstatin (Pep.) $100 \mu \mathrm{m} / \mathrm{ml}$, Chloroquine (Chlor.) $75 \mu \mathrm{M}$. Values on the $\mathrm{Y}$-axis are the "increments" of total and free cholesterol in macrophages during incubation, expressed as mean $+S D(n=3) .{ }^{*} p<0.05,{ }^{* *} p<0.005$, $* * * \mathrm{p}<0.001$ vs control.

exhibited an additive effect.

\section{Effect of inhibitors on $\left[{ }^{3} \mathrm{H}\right]$ oleate incorporation}

Incorporation of $\left[{ }^{3} \mathrm{H}\right]$ oleate into cellular cholesteryl $\left[{ }^{3} \mathrm{H}\right]$ oleate was significantly suppressed by leupeptin, pepstatin, and chloroquine (Table 2). These suppression of $\left[{ }^{3} \mathrm{H}\right]$ oleate incorporation into cholesteryl $\left[{ }^{3} \mathrm{H}\right]$ oleate seems to be due to decreased liberation of free cholesterol from acetyl-LDL in macrophages.

\section{Effect of protease inhibitors on cellular contents of total} and free cholesterol

After an incubation with $100 \mu \mathrm{g} / \mathrm{ml}$ of acetyl-LDL for 5 hours, total cholesterol content in macrophages was significantly increased from $10.6 \pm 0.6$ to $16.7 \pm 1.0 \mathrm{nmol} /$ well $(n=3, p<0.001)$ or from $27.0 \pm 3.7$ to $60.9 \pm 3.5 \mathrm{nmol} /$ $\mathrm{mg}$ cell protein $(\mathrm{p}<0.001)$. Free cholesterol content was also increased from $8.0 \pm 0.8$ to $11.1 \pm 0.6 \mathrm{nmol} /$ well $(n=3$, $p<0.01$ ) or from $30.1 \pm 2.7$ to $40.3 \pm 3.2 \mathrm{nmol} / \mathrm{mg}$ cell protein $(p<0.05)$. Fig. 1 shows the increments of cellular total and free cholesterol contents after incubation. The increase in cellular cholesterol content was enhanced in the presence of protease inhibitors. Compared with the inhibition of apolipoprotein degradation, increments of cholesterol content caused by leupeptin and/or pepstatin seemed to be relatively small.

\section{Discussion}

In this study, we have demonstrated that both lysosomal protease inhibitors, leupeptin and pepstatin A, suppressed the acetyl-LDL degradation in cultured macrophages. Leupeptin inhibits thiol proteases and pepstatin A inhibits cathepsin $D(14-16)$. Our finding indicates that both the thiol proteases and cathepsin D participate in the intracellular degradation of lipoproteins, which is consistent with the in vitro result of Rankin et al. who investigated the effect of proteases on LDL using whole-cell sonicates of macrophages (3).

The actual concentration of protease inhibitors attained in lysosomes was not measured in this experiment. In our previous work, leupeptin was easily incorporated into thyroid lysosomes within 2 hours in the organ culture of rat thyroid glands $(15,16)$. Aulinskas et al. reported the inhibition of LDL degradation by the addition of $100 \mu \mathrm{g} / \mathrm{ml}$ of leupeptin to cultured smooth muscle cell media (17). On the other hand, pepstatin is not readily introduced into lysosomes (14-16). Therefore, the role of cathepsins in the degradation of lipoproteins has been investigated by in vitro methods using such as sonicated macrophages (3), subcellular fraction of macrophages (4), or cathepsin itself (5). In this experiment, pepstatin in the media inhibited the degradation of acetyl-LDL in the cell culture system as well as leupeptin did. As for the chloroquine, it was reported that chloroquine inhibited both the degradation of apolipoprotein and the incorporation of oleic acid into cellular cholesteryl-oleate in macrophages incubated with acetyl-LDL $(1,11)$.

In addition to those phenomena, in our study, chloroquine caused a prominent increase in cholesterol contents in macrophages. Such changes in cholesterol metabolism seem to be attributed to the suppression of the release of free cholesterol from lysosomes owing to the inhibited hydroxylation of cholesterol esters contained in lipoproteins, because this novel lysosomotrophic agent is considered to inhibit both acid proteases and acid 
lipase by elevating intralysosomal $\mathrm{pH}(18)$. Interestingly, the inhibition of lysosomal proteases by leupeptin and/or pepstatin also led to an increase in cellular cholesterol contents and an inhibition of the $\left[{ }^{3} \mathrm{H}\right]$ oleate incorporation. It is suggested that the inhibition of proteases by itself could, at least in part, suppress the release of cholesterol from lipoprotein. These changes by protease inhibitors, however, seemed to be less effective than those induced by chloroquine. Lipoprotein is complex of phospholipids, and free and esterified cholesterols. Therefore, cooperation of various hydrolases seems to be necessary for lysosomal liberation of cholesterols from lipoproteins.

It is concluded that leupeptin and pepstatin A inhibited the degradation of acetyl-LDL in cultured macrophages. The inhibition of the degradation of acetyl-LDL by leupeptin and pepstatin indicates the importance of thiol proteases and cathepsin $D$ in the lysosomal degradation of lipoproteins. Since the protease inhibitors also suppressed $\left[{ }^{3} \mathrm{H}\right]$ oleate incorporation and increased the cellular cholesterol content, the breakdown of apolipoproteins seems to be necessary for the complete release of free cholesterol from lipoproteins.

Acknowledgment: This work was supported by a grant in-aid for encouragement of young scientists from the Ministry of Education, Science and Culture (No. 63770413).

\section{References}

(1) Brown MS, Goldstein JL, Krieger M, Ho YK, and Anderson RW : Reversible accumulation of cholesteryl esters in macrophages incubated with acetylated lipoproteins. J Cell Biol, 82 : 597-613, 1979

(2) Brown MS, Ho YK, and Goldstein JL: The cholesteryl ester cycle in macrophage foam cells. J Biol Chem, 255: 9344-9352, 1980

(3) Rankin SM, Knowles ME, and Leake DS: Macrophage possess both neutral and acidic protease activities toward low density lipoproteins. Atherosclerosis, 79 : 71-78, 1989

(4) Van Lenten BJ and Fogelman A :. Processing of lipoproteins in human monocyte-macrophages. $J$ Lipid Res, 31 : 1455-1466,1990

(5) Lougheed M, Zhang $H$, and Steinbrecher UP: Oxidized low density liprotein is resistant to cathepsins and accumulates within macrophages. J Biol Chem, 266 : 1451914525, 1991

(6) Havel RJ, Eder HA, and Bragdon $\mathrm{JH}$ : The distribution and chemical composition of ultracentrifugally separated lipoproteins in human serum. J Clin Invest, 34 : 13451353, 1955

(7) Fraenkel-Cornat $\mathrm{H}$ : Methods for investigating the essential group for enzyme activity. Methods Enzymol, 4: 247-269, 1975

(8) McFarlane AS : Efficient trace-labelling of proteins with iodine. Nature, $4627: 53,1958$

(9) Bilheimer DW, Eisenberg S, and Levy RI: The metabolism of very low density lipoproteins. Biochim Biophys Acta, 260 : 212-221, 1972

(10) Goldstein JL, Dana SE, and Brown MS : Esterification of low density lipoprotein cholesterol in human fibroblasts and its absence in homozygous familial hypercholesterolemia. Proc Natl Acad Sci USA, 71: 4288-4292, 1974

(11) Goldstein JL, Ho YK, Basu SK, and Brown MS : Binding site on macrophage that mediates uptake and degradation of acetylated low density lipoprotein, producing massive cholesterol deposition. Proc Natl Acad Sci USA, 76: 333-337, 1979

(12) Goldstein JL and Brown MS : Binding and degradation of low density lipoproteins by cultured human fibroblast. J Biol Chem, 249: 5153-5162, 1974

(13) Gamble W, Vaughan M, Kruth HS, and Avigan J: Procedure for determination of free and total cholesterol in micro- or nonogram amounts suitable for studies with cultured cells. J Lipid Res, 19: 1068-1070, 1978

(14) Dean RT : Direct evidence of importance of lysosomes in degradation of intracellular proteins. Nature, 257: 414416, 1975

(15) Yoshinari $M$ and Taurog $A$ : Physiological role of thiol proteases in thyroid hormone secretion. Acta Endocrinol (Copenh), 113: 261-267, 1986

(16) Yoshinari $M$ and Taurog $A$ : Lysosomal digestion of thyroglobulin: Role of cathepsin D and thiol proteases. Endocrinology, 117 : 1621-1631, 1985

(17) Aulinskas TH, Coetzee GA, and Van Der Westhuyzen DR: Degradation of apolipoprotein B of low density lipoprotein by cultured bovine smooth muscle cells. Accumulation of intermediates in the presence of protease inhibitors. Biochim Biophys Acta, 663: 421431, 1981

(18) Wibo $M$ and Poole $B$ : Protein degradation in cultured cells. II. The uptake of chloroquine by rat fibroblasts and the inhibition of cellular protein degradation and cathepsin B1. J Cell Biol, 63 : 430-440, 1974 